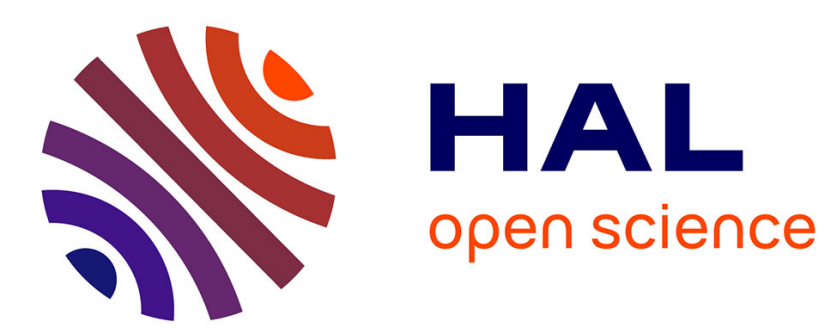

\title{
High temperature corrosion of water wall tube in coalfired combustion gases
}

\author{
K. Nakagawa, M. Kitagawa, Y. Tumita, S. Ooki
}

\section{To cite this version:}

K. Nakagawa, M. Kitagawa, Y. Tumita, S. Ooki. High temperature corrosion of water wall tube in coalfired combustion gases. Journal de Physique IV Proceedings, 1993, 03 (C9), pp.C9-787-C9-796. 10.1051/jp4:1993982 . jpa-00252424

\section{HAL Id: jpa-00252424 https://hal.science/jpa-00252424}

Submitted on 1 Jan 1993

HAL is a multi-disciplinary open access archive for the deposit and dissemination of scientific research documents, whether they are published or not. The documents may come from teaching and research institutions in France or abroad, or from public or private research centers.
L'archive ouverte pluridisciplinaire HAL, est destinée au dépôt et à la diffusion de documents scientifiques de niveau recherche, publiés ou non, émanant des établissements d'enseignement et de recherche français ou étrangers, des laboratoires publics ou privés. 


\title{
High temperature corrosion of water wall tube in coalfired combustion gases
}

\author{
K. Nakagawa $\left({ }^{1}\right)$, M. Kitagawa $\left({ }^{1}\right)$, Y. Tumita $\left({ }^{2}\right)$ and S. Ooki $\left({ }^{3}\right)$
}

( $\left.{ }^{1}\right)$ Research Institute, Ishikawajima-Harima Heavy Industries Co., Ltd. 1-15 Toyosu 3-chome, Koto-ku Tokyo 13, Japan

(2) Boiler Basic Design Department, Ishikawajima-Harima Heavy Industries Co., Ltd. 1-15, Toyosu 3-chome, Koto-ku Tokyo 13, Japan

$\left({ }^{3}\right)$ Electric Power Research \& Development Center, Chubu Electric Company Incorporated, Kitasekiyama 20-1 Ohdaka-Cho Midori-Ku Nagoya 459, Japan

\begin{abstract}
The effect of stoichiometry ratio and ash deposits on the corrosion of mild steel and $0.5 \mathrm{Cr}-0.5 \mathrm{Mo}$ steel has been investigated at $450{ }^{\circ} \mathrm{C}$ in the simulated combustion gases burning three kinds of coals. Under the assumption that the gas reacts with the metal at the same temperature as the surface and gas has not changed in composition, the corrosion behavior could be estimated from the Fe-S-O phase stability diagram at $450{ }^{\circ} \mathrm{C}$ and pseudo equilibrium $P_{\mathrm{s}_{2}}$ and $P_{\mathrm{O}_{2}}$ based on $\mathrm{H}_{2} \mathrm{O}: \mathrm{H}_{2}$ at $120{ }^{\circ} \mathrm{C}$ for simulated combustion gases. Ash deposits accelerated the corrosion rates of steels. It is considered that ash deposits act as catalyst and shift the gas composition to the low temperature equilibrium state.
\end{abstract}

\section{Introduction.}

Recently substoichiometric combustion has been employed in pulverized coal fired boilers to reduce $\mathrm{NO}_{x}$ concentration [1]. Sulfur is released from coal as $\mathrm{H}_{2} \mathrm{~S}$, which sulfidizes boiler tubes at furnace wall temperatures. Sulfide scales are much less protective than oxide scales, and metal sulfidation rates are much higher than oxidation rates. Severe corrosion of furnace wall tubes is expected to take place particularly when firing high sulfur coals.

In a pulverized coal fired boiler a large amount of ash deposits on the water wall tube surfaces. The ash deposition on the tube surface would influence the corrosion behavior. The effect of the ash deposit, however, on the corrosion of water wall tubes has not been well understood.

In this study the effect of stoichiometry ratio and ash deposition on the corrosion behavior of the candidate materials of water wall tubes has been investigated in simulated combustion gases at furnace wall temperature.

\section{Experimental procedure.}

A mild steel and a $0.5 \mathrm{Cr}-0.5 \mathrm{Mo}$ steel were used in this test. The chemical compositions of materials are given in table I. Corrosion tests were carried out in simulated combustion gases burning Illinois No.6, Daido and Taiheiyo coals at several stoichiometric combustions. The gas temperature during combustion was estimated to be $1200^{\circ} \mathrm{C}$. The chemical compositions 
of coals and the thermodynamic equilibrium compositions of combustion gases are presented in tables II and III, respectively. Specimens $(7.5 \mathrm{~mm} \times 15 \mathrm{~mm} \times 3 \mathrm{~mm})$ surfaces were ground by \# 600 emery papers and degreased by acetone. These specimens were placed in the apparatus and kept at $450{ }^{\circ} \mathrm{C}$ for $1000 \mathrm{~h}$ max. The gas flow rate during the experiments was $1000 \mathrm{cc} / \mathrm{min}$. The effect of ash deposits on the corrosion behavior of the mild and the low alloy steels was also investigated. The ash was extracted from a water wall tubes of a coal fired boiler. The chemical composition of the ash is shown in table IV.

Table I. - Chemical compositions of steels used (wt\%).

\begin{tabular}{|c|c|c|c|c|c|c|c|}
\hline Material & $\mathrm{C}$ & $\mathrm{Si}$ & $\mathrm{Mn}$ & $\mathrm{P}$ & $\mathrm{S}$ & $\mathrm{Cr}$ & Mo \\
\hline Mild steel & 0.21 & 0.23 & 0.75 & 0.020 & 0.020 & - & - \\
\hline $0.5 \mathrm{Cr}-0.5 \mathrm{MO}$ steel & 0.13 & 0.34 & 0.53 & 0.014 & 0.011 & 0.52 & 0.57 \\
\hline
\end{tabular}

The corrosion resistance was evaluated by the surface recession measured by the microscopic observation of cross sections of specimens or mass increase of the specimens after the test. The scales on the corroded specimen surfaces were analyzed by EPMA. Scale components were also identified by X-ray diffraction.

Table II. - Chemical compositions of coals (wt\%).

\begin{tabular}{|c|c|c|c|}
\hline Bland & Illinois No.6 & Daido & Taiheiyo \\
\hline Total Moisture & 12.0 & 10.3 & 11.0 \\
\hline Ash & 16.0 & 9.2 & 15.4 \\
\hline C & 57.5 & 76.2 & 65.7 \\
\hline H & 3.7 & 4.3 & 5.2 \\
\hline N & 0.9 & 0.87 & 1.0 \\
\hline S & 4.0 & 0.68 & 0.3 \\
\hline O & 5.8 & 6.0 & 11.9 \\
\hline
\end{tabular}

Continuous weight gain measurements of the mild steel were also conducted in simulated combustion gases by using thermogravimetry to investigate the corrosion rate law. Before the start of the experiments the air in the retort was replaced with flowing $\mathrm{N}_{2}$ gas. The gas flow rate of the gas mixture experiments was $200 \mathrm{cc} / \mathrm{min}$. 
Table III. - Thermodynamic equilibrium compositions of combustion gases. (vol\%).

\begin{tabular}{|c|c|c|c|c|c|c|c|c|c|}
\hline coals & $\begin{array}{c}\text { Stoichiometric } \\
\text { ratio }\end{array}$ & $\begin{array}{c}\text { Gas } \\
\text { reference }\end{array}$ & $\mathrm{CO}$ & $\mathrm{CO}_{2}$ & $\mathrm{H}_{2} \mathrm{O}$ & $\mathrm{H}_{2}$ & $\mathrm{SO}_{2}$ & $\begin{array}{c}\mathrm{H}_{2} \mathrm{~S} \\
(\mathrm{ppm})\end{array}$ & $\mathrm{N}_{2}$ \\
\hline Illinois & 0.7 & A & 11.2 & 10.1 & 8.1 & 2.8 & 0.1 & 1690 & Bal. \\
\hline No.6 & 0.8 & B & 7.1 & 12.3 & 8.5 & 1.5 & 0.28 & 693 & Bal. \\
\hline & 0.9 & $\mathrm{C}$ & 3.5 & 14.3 & 8.6 & 0.66 & 0.44 & 84 & Bal. \\
\hline & 0.7 & D & 12.2 & 9.9 & 7.2 & 2.8 & 0.02 & 360 & Bal. \\
\hline Daido & 0.8 & E & 7.7 & 12.5 & 7.7 & 1.5 & 0.05 & 130 & Bal. \\
\hline & 0.9 & F & 3.6 & 14.9 & 7.8 & 0.6 & 0.06 & 10 & Bal. \\
\hline & 0.7 & $G$ & 11.5 & 9.7 & 9.0 & 3.3 & 0.01 & 200 & Bal. \\
\hline Taiheiyo & 0.8 & $\mathrm{H}$ & 7.2 & 12.1 & 9.5 & 1.8 & 0.02 & 70 & Bal. \\
\hline & 0.9 & $\mathrm{I}$ & 3.4 & 14.4 & 9.7 & 0.7 & 0.03 & 6 & Bal. \\
\hline
\end{tabular}

Table IV. - The chemical composition of ash used (wt\%).

\begin{tabular}{|c|c|c|c|c|c|c|c|}
\hline Component & $\mathrm{SiO}_{2}$ & $\mathrm{Al}_{2} \mathrm{O}_{3}$ & $\mathrm{Fe}_{2} \mathrm{O}_{3}$ & $\mathrm{CaO}$ & $\mathrm{ZnO}$ & $\mathrm{SO}_{3}$ & $\mathrm{C}$ \\
\hline Actual ash & 57.3 & 23.4 & 4.7 & 3.2 & 2.6 & 2.0 & 0.5 \\
\hline
\end{tabular}

\section{Test results and discussion.}

3.1 Thermodynamic Consideration. - Before the corrosion tests, we try to predict the corrosion behavior of mild steel and $0.5 \mathrm{Cr}-0.5 \mathrm{Mo}$ steel from the Fe-S-O phase diagram and pseudo-equilibrium sulfur and oxygen pressures for simulated combustion gases. The gas temperature at the surface of waterwall tube can approach the metal temperature of $450{ }^{\circ} \mathrm{C}$. The nature of the boundary layer including its thickness, and temperature/composition gradients has not been analyzed. Therefore, some elementary assumptions were made. The first is that the gas reacts with the metal at $450{ }^{\circ} \mathrm{C}$. The second is that the gas composition is not changed. Reaction kinetics in bulk gas seems to be very slow and gas flow velocity is very high [2]. It is considered likely that the gas passes through the waterwall area with a little change in composition. It is necessary to calculate pseudo-equilibrium sulfur and oxygen pressures for the high temperature gas composition at a low gas/surface temperature. As we have estimated that the combustion gas temperature is $1200^{\circ} \mathrm{C}$ the $P_{\mathrm{O}_{2}}$ is calculated by using the $1200{ }^{\circ} \mathrm{C}$ equilibrium ratios of $\mathrm{H}_{2} \mathrm{O}: \mathrm{H}_{2}$ or $\mathrm{CO}_{2}: \mathrm{CO}$, and the equilibrium constants at $450{ }^{\circ} \mathrm{C}$. Similarly, $P_{\mathrm{S}_{2}}$ is calculated by using $1200^{\circ} \mathrm{C}$ equilibrium ratios of $\mathrm{H}_{2} \mathrm{~S}: \mathrm{H}_{2}$. These pseudo equilibrium sulfur and oxygen pressures are shown in table V. The calculated pseudo equilibrium $P_{\mathrm{O}_{2}}$ and $P_{\mathrm{S}_{2}}$ of the gas mixtures used in this study were superimposed on the $\mathrm{Fe}-\mathrm{S}-\mathrm{O}$ phase diagram at $450^{\circ} \mathrm{C}$ as shown in figure 1 . From this diagram we can predict if Fe tends to form sulfide or oxide in combustion gases under several conditions. Namely, Fe tends to form the sulfide in the range of pseudo equilibrium $P_{\mathrm{O}_{2}}$ and $P_{\mathrm{S}_{2}}$ values based on 
Table V. - Pseudo equilibrium sulfur and oxygen pressures (atm).

\begin{tabular}{|c|c|c|c|c|c|}
\hline & \multicolumn{2}{|c|}{ Equilibrated } & $\left(450^{\circ} \mathrm{C}\right)$ & \multicolumn{3}{|c|}{ Not Equilibrated } \\
\hline $\begin{array}{c}\text { Gas } \\
\text { Reference }\end{array}$ & $\log P_{\mathrm{O}_{2}}$ & $\log P_{\mathrm{S}_{2}}$ & $\begin{array}{c}\log P_{\mathrm{O}_{2}} \\
\left(\mathrm{H}_{2} \mathrm{O}: \mathrm{H}_{2}\right)\left({ }^{1}\right)\end{array}$ & $\begin{array}{c}\log P_{\mathrm{O}_{2}} \\
\left(\mathrm{CO}_{2}: \mathrm{CO}\right)\left({ }^{1}\right)\end{array}$ & $\begin{array}{c}\log P_{\mathrm{S}_{2}} \\
\left(\mathrm{H}_{2} \mathrm{~S}: \mathrm{H}_{2}\right)\left({ }^{2}\right)\end{array}$ \\
\hline A & -29.37 & -9.45 & -28.98 & -31.83 & -10.33 \\
\hline B & -29.36 & -9.44 & -28.39 & -31.26 & -10.56 \\
\hline C & -29.04 & -9.20 & -27.67 & -30.52 & -11.68 \\
\hline D & -29.37 & -11.10 & -29.08 & -31.92 & -11.67 \\
\hline E & -29.36 & -11.10 & -28.48 & -31.32 & -12.01 \\
\hline F & -29.35 & -11.09 & -27.67 & -30.51 & -13.45 \\
\hline G & -29.39 & -11.97 & -29.03 & -31.89 & -12.32 \\
\hline $\mathrm{H}$ & -29.38 & -11.96 & -28.46 & -31.29 & -12.71 \\
\hline I & -29.30 & -11.90 & -27.62 & -30.49 & -14.02 \\
\hline
\end{tabular}

( ${ }^{1}$ ) $\log P_{\mathrm{O}_{2}}$ calculated using the $\mathrm{H}_{2} \mathrm{O}: \mathrm{H}_{2}$ or $\mathrm{CO}_{2}$ : $\mathrm{CO}$ ratios of the equilibrium gas composition at $1200^{\circ} \mathrm{C}$ and the Gibbs Free Energy at $450^{\circ} \mathrm{C}$.

$\left.{ }^{2}\right) \log P_{\mathrm{S}_{2}}$ calculated in a similar manner using $\mathrm{H}_{2} \mathrm{~S}: \mathrm{H}_{2}$ ratios and free energy data.

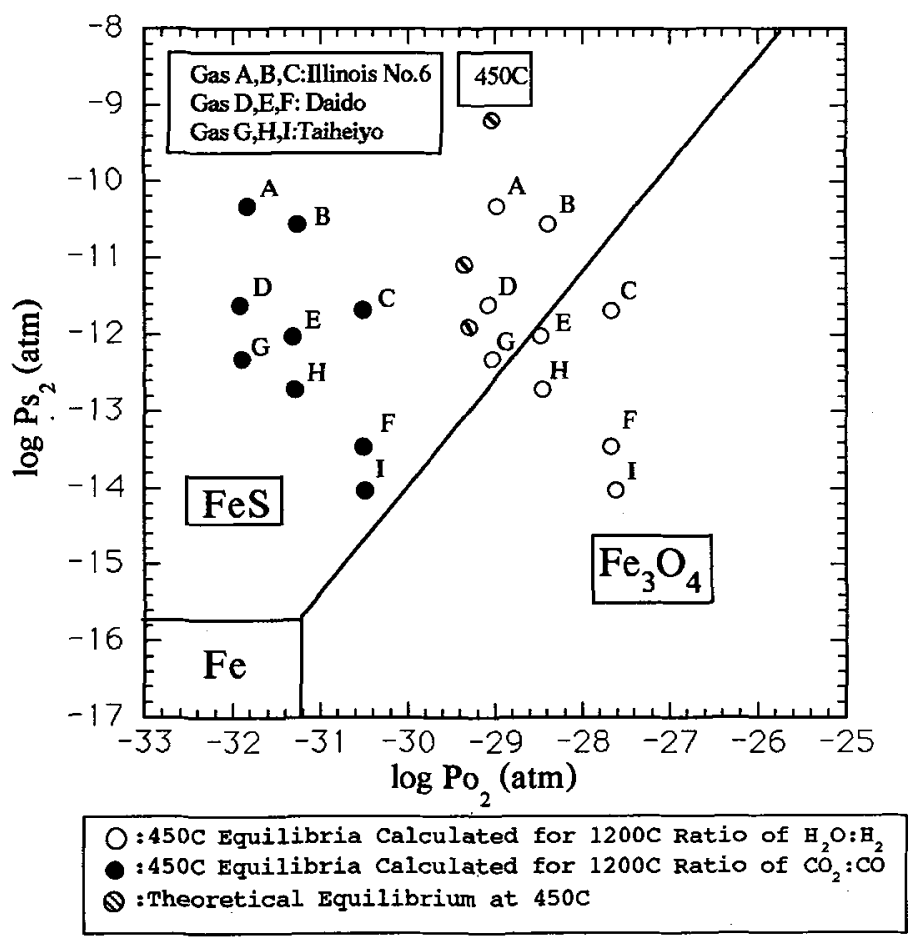

Fig. 1. - Fe-S-O Equilibrium phase diagram at $450{ }^{\circ} \mathrm{C}$. 
$\mathrm{CO}_{2}$ : $\mathrm{CO}$ ratios at $1200^{\circ} \mathrm{C}$. However, the range of those based on $\mathrm{H}_{2} \mathrm{O}: \mathrm{H}_{2}$ ratios at $1200^{\circ} \mathrm{C}$ are located at the boundary between $\mathrm{FeS}$ and $\mathrm{Fe}_{3} \mathrm{O}_{4}$.

3.2 CORROSION TEST RESULTS. - Table VI shows the corrosion test results of the mild steel and $0.5 \mathrm{Cr}-0.5 \mathrm{Mo}$ steel in simulated combustion gases. The corrosion rates of the both steels were almost the same. Severe corrosion was observed on the steels in simulated combustion gases under stoichiometry ratio of 0.7 (gases A, D, G). Figure $2 \mathrm{a}$ shows the cross sectional photomicrograph of $0.5 \mathrm{Cr}-0.5 \mathrm{Mo}$ steels after exposure in gas A for $500 \mathrm{~h}$. The X-ray diffraction and EPMA analysis showed that the outer layer scales consisted of $\mathrm{FeS}$, and the inner scales consisted of a mixtures of $\mathrm{FeS}$ and $\mathrm{Fe}_{3} \mathrm{O}_{4}$. The corrosion rates of the steels were high in gas $\mathrm{B}$ simulating the combustion environment burning the high sulfur Illinois No. 6 coal under stoichiometry ratio of 0.8 . However, the corrosion rates were small in gases $\mathrm{E}, \mathrm{H}$ simulating the combustion environments burning Daido and Taiheiyo coals, respectively under the same stoichiometry ratio. The corrosion rates were also very small in gases $\mathrm{C}, \mathrm{F}, \mathrm{I}$ simulating the combustion environments under stoichiometry ratio of 0.9 . The scales formed on $0.5 \mathrm{Cr}-0.5 \mathrm{Mo}$ steel in gas 1 were very thin and adherent as shown in figure $2 \mathrm{~b}$, which were identified as $\mathrm{Fe}_{3} \mathrm{O}_{4}$.

Table VI. - Max-surface recessions of steels in simulated combustion gases at $450^{\circ} \mathrm{C}$.

\begin{tabular}{|c|c|c|c|c|c|c|c|}
\hline & \multicolumn{6}{|c|}{ Max. Surface Recession (/an) } \\
\hline & & \multicolumn{2}{|c|}{$100 \mathrm{~h}$} & \multicolumn{2}{|c|}{$500 \mathrm{~h}$} & \multicolumn{2}{|c|}{$1000 \mathrm{~h}$} \\
\hline Material & $\begin{array}{c}\text { Gás } \\
\text { reference }\end{array}$ & No deposit & with deposit & No deposit & with deposit & No deposil & with deposit \\
\hline $\begin{array}{c}0.5 \mathrm{Cr}-0.5 \mathrm{Mo} \\
\text { Steel }\end{array}$ & $\begin{array}{c}A \\
B \\
C \\
D \\
E \\
F \\
G \\
H \\
I\end{array}$ & $\begin{array}{c}26.3 \\
27.5 \\
5.0 \\
22.5 \\
10.0 \\
3.3 \\
30.0 \\
7.0 \\
5.0\end{array}$ & $\begin{array}{c}33.8 \\
52.5 \\
5.5 \\
27.5 \\
17.5 \\
6.3 \\
20.0 \\
7.5 \\
5.0\end{array}$ & $\begin{array}{c}88.0 \\
- \\
7.0 \\
75.0 \\
50.0 \\
- \\
- \\
- \\
6.8\end{array}$ & $\begin{array}{c}130.0 \\
- \\
40.0 \\
155.0 \\
80.0 \\
- \\
- \\
- \\
7.0 \\
\end{array}$ & $\begin{array}{c}- \\
- \\
- \\
110.0 \\
- \\
- \\
- \\
- \\
8.5 \\
\end{array}$ & $\begin{array}{c}- \\
- \\
- \\
160.0 \\
- \\
- \\
- \\
- \\
8.0 \\
\end{array}$ \\
\hline Mild steel & $\begin{array}{l}A \\
B \\
C \\
D \\
E \\
\mathrm{I} \\
\mathrm{G} \\
11 \\
\mathrm{I}\end{array}$ & $\begin{array}{l}25.0 \\
20.0 \\
5.0 \\
17.5 \\
3.8 \\
3.8 \\
22.5 \\
7.5 \\
5.0\end{array}$ & $\begin{array}{c}32.5 \\
25.0 \\
5.0 \\
22.5 \\
12.5 \\
3.8 \\
17.5 \\
5.0 \\
5.0\end{array}$ & $\begin{array}{c}100.0 \\
- \\
7.0 \\
- \\
70.0 \\
75.0 \\
- \\
- \\
7.0\end{array}$ & $\begin{array}{c}120.0 \\
- \\
20.5 \\
- \\
150.0 \\
90.0 \\
- \\
- \\
7.0\end{array}$ & $\begin{array}{c}- \\
- \\
- \\
- \\
100.0 \\
- \\
- \\
- \\
8.75\end{array}$ & $\begin{array}{c}- \\
- \\
- \\
- \\
1<10.0 \\
- \\
- \\
- \\
7.5\end{array}$ \\
\hline
\end{tabular}

Pseudo equilibrium $P_{\mathrm{S}_{2}}$ and $P_{\mathrm{O}_{2}}$ based on $\mathrm{CO}_{2}$ : CO ratios predicted sulfide formations in all atmosphere tested. Low temperature equilibrium $P_{\mathrm{S}_{2}}$ and $P_{\mathrm{O}_{2}}$ also predicted sulfide formations in all cases. However, the results were quite contrary. The corrosion rates of $0.5 \mathrm{Cr}$ $0.5 \mathrm{Mo}$ steel were superimposed on the applicable gas equilibrium based on $\mathrm{H}_{2} \mathrm{O}: \mathrm{H}_{2}$ ratios 


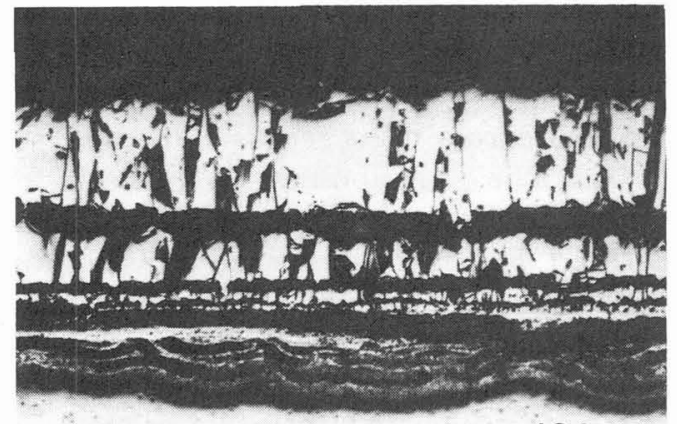

$100 \mu \mathrm{m}$

(a)

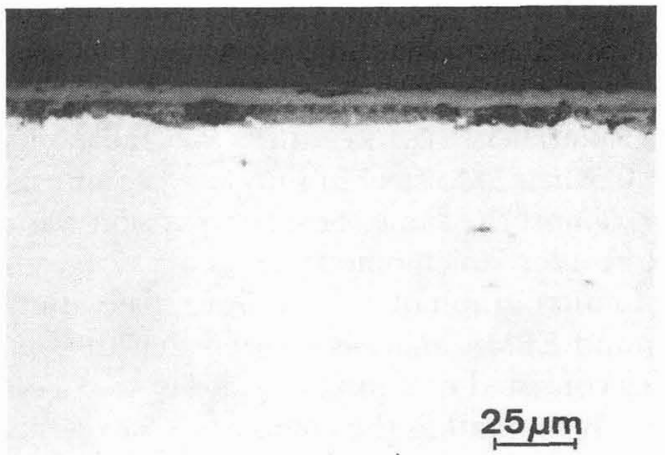

(b)

Fig. 2. - Scales formed on $0.5 \mathrm{Cr}-0.5 \mathrm{Mo}$ in gas $\mathrm{A}$ and gas $\mathrm{H}$ at $450^{\circ} \mathrm{C}$ for $500 \mathrm{~h}$ : a) in gas $\mathrm{A}$; b) in gas $\mathrm{H}$.

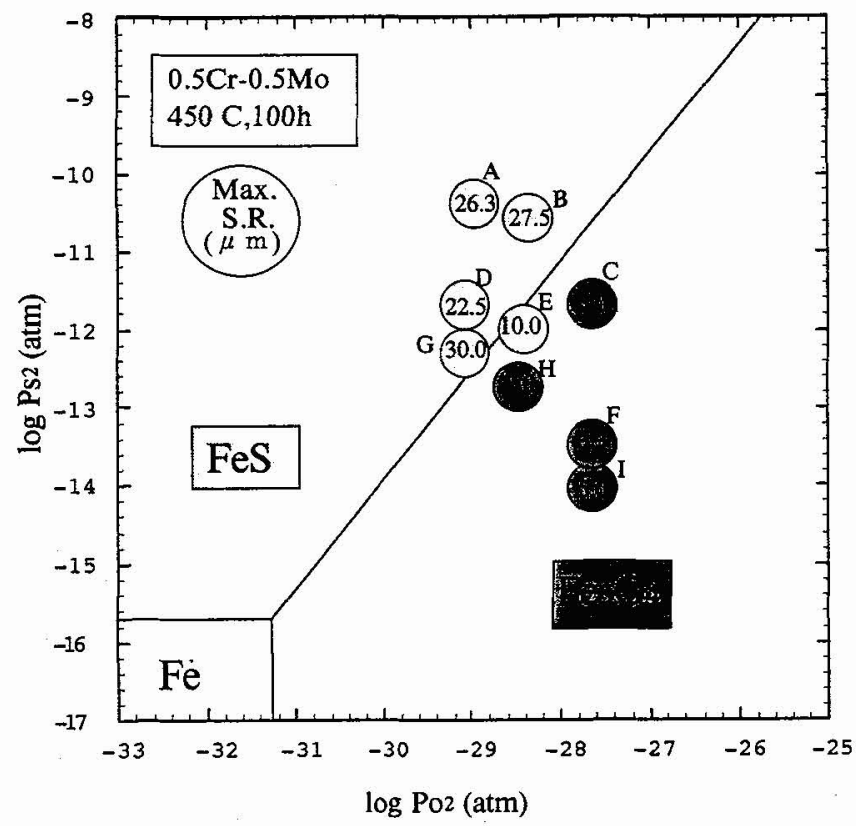

Fig. 3. - Max-surface recessions of $0.5 \mathrm{Cr}-0.5 \mathrm{Mo}$ steel in simulated combustion gases at $450{ }^{\circ} \mathrm{C}$ for $100 \mathrm{~h}$.

at $1200^{\circ} \mathrm{C}$ in the Fe-S-O phase diagram as shown in figure 3. Where the pseudo equilibrium positions of simulated combustion gases were in the FeS stable field the corrosion rates of $0.5 \mathrm{Cr}-0.5 \mathrm{Mo}$ steel were high. However, the corrosion rates were very low in the atmospheres where $\mathrm{Fe}_{3} \mathrm{O}_{4}$ was expected to form. Thus the estimation using pseudo equilibrium $P_{\mathrm{S}_{2}}$ and $P_{\mathrm{O}_{2}}$ based on $\mathrm{H}_{2} \mathrm{O}: \mathrm{H}_{2}$ ratios were well consistent with test results. It seemed therefore that the gas composition has not drastically changed in the corrosion apparatus. These data 


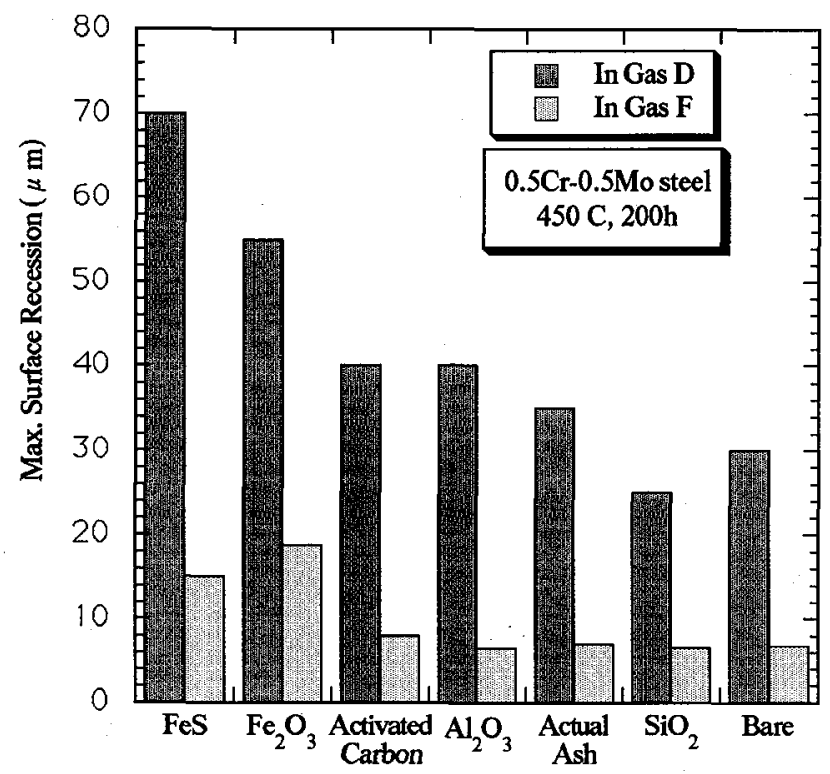

Fig. 4. - Effect of deposition of ash components on the corrosion rates of $0.5 \mathrm{Cr}-0.5 \mathrm{Mo}$ steels.

suggest that it may be possible to predict the corrosion behavior of waterwall tubes from the Fe-S-O phase diagram and pseudo-equilibrium $P_{\mathrm{S}_{2}}$ and $P_{\mathrm{O}_{2}}$ based on $\mathrm{H}_{2} \mathrm{O}: \mathrm{H}_{2}$ and $\mathrm{H}_{2} \mathrm{~S}: \mathrm{H}_{2}$ ratios at $1200^{\circ} \mathrm{C}$ for a simulated combustion gas.

Ash deposit slightly accelerated the corrosion rates. Ash deposition on the tube surface may influence the gas phase reactions. Also, ash deposits prevent from forming uniform outer scales and may make it easy to transport sulfur containing species to the metallic surface. However, the mechanism is not clear as yet. As shown in table IV ash contains various components such as $\mathrm{SiO}_{2}, \mathrm{Al}_{2} \mathrm{O}_{3}, \mathrm{Fe}_{2} \mathrm{O}_{3}, \mathrm{FeS}$ and unburned coal et al. The effect of these ash components on the corrosion of $0.5 \mathrm{Cr}-0.5 \mathrm{Mo}$ steel was investigated. Figure 4 shows the corrosion rates of $0.5 \mathrm{Cr}-0.5 \mathrm{Mo}$ steel covered with various ash components. $\mathrm{Fe}_{2} \mathrm{O}_{3}$ and $\mathrm{FeS}$ remarkably increase the corrosion rates. Activated carbon also increased the corrosion rates but the influence was not remarkable like that of $\mathrm{Fe}_{2} \mathrm{O}_{3}$ and $\mathrm{FeS} . \mathrm{Al}_{2} \mathrm{O}_{3}$ and $\mathrm{SiO}_{2}$ did not appreciably change the corrosion rates. $\mathrm{Fe}_{2} \mathrm{O}_{3}$ and $\mathrm{FeS}$ also increased the corrosion rates even in oxide stable atmosphere. As shown in figure 5, EPMA maps of the scales indicate that sulfide increased in the inner scales. These results suggest that $\mathrm{Fe}_{2} \mathrm{O}_{3}$ and $\mathrm{FeS}$ act as catalyst and the gas composition has changed to its low temperature equilibrium. Thus, the $P_{\mathrm{S}_{2}}$ near the metal surface and consequently the corrosion rates would increase. The acceleration mechanism of the activated carbon seems rather different. Carbon may serve as a buffer to maintain low oxygen concentration as reported by Harb et al. [3]. From these investigations, it became clear that the effect of ash deposit highly depends on its composition. Therefore the increase of the corrosion rate can not be determined quantitatively at present.

It is well known that the corrosivity of reducing gas depends on its $\mathrm{H}_{2} \mathrm{~S}$ concentration [4]. Figure 6 shows the effect of $\mathrm{H}_{2} \mathrm{~S}$ content on the corrosion rates of the mild steel and $0.5 \mathrm{Cr}-0.5 \mathrm{Mo}$ steel in simulated combustion gases at $450^{\circ} \mathrm{C}$ for $100 \mathrm{~h}$. The corrosion rates increased with increasing $\mathrm{H}_{2} \mathrm{~S}$ content in a low $\mathrm{H}_{2} \mathrm{~S}$ range. However, the corrosion rates tend 


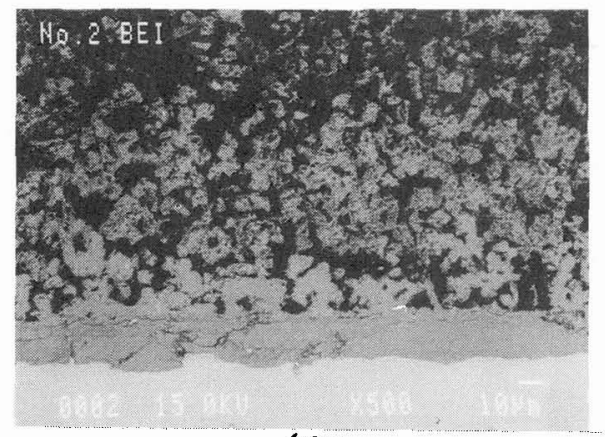

(a)

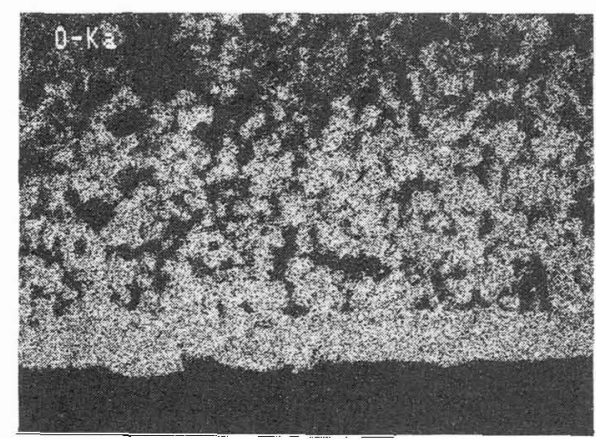

(C)

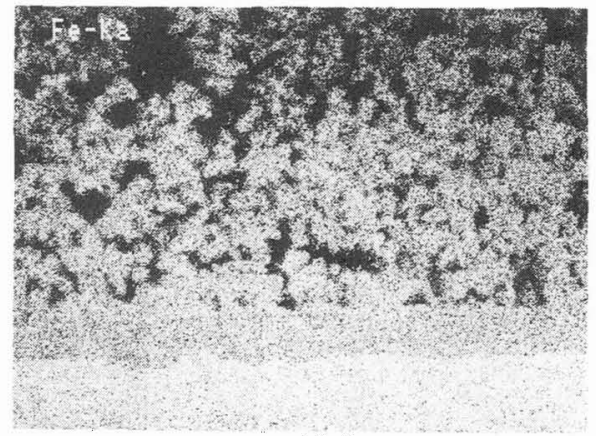

(b)

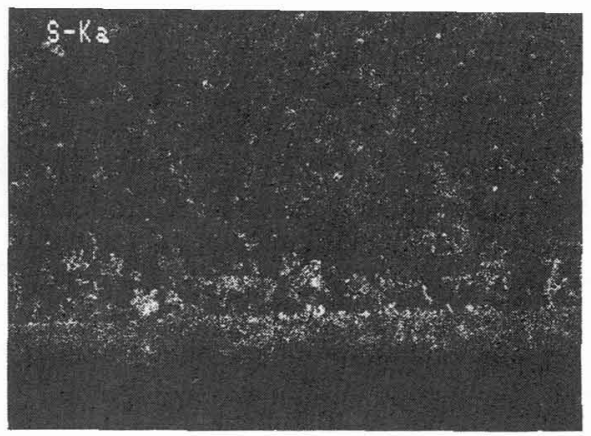

(d)

Fig. 5. - Scales formed on 0.5Cr-0.5Mo coved with $\mathrm{Fe}_{2} \mathrm{O}_{3}$ in gas $\mathrm{F}$ at $450{ }^{\circ} \mathrm{C}$ for $200 \mathrm{~h}$ : a) B.S.E.; b) iron; c) oxygen; d) sulfur.

to saturate in high $\mathrm{H}_{2} \mathrm{~S}$ content region. Also, the corrosion rates remained low with levels up

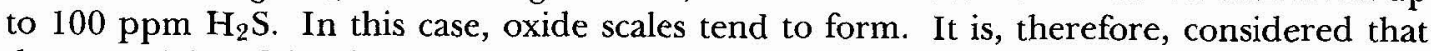
the corrosivity of simulated combustion gas depends not only on $\mathrm{H}_{2} \mathrm{~S}$ content but also on the oxygen pressure.

3.3 CoRrosion KINETICS. - - It is necessary to know the corrosion rate law in order to estimate long term behavior from short time data. For this purpose, mass increases of the mild steel were continuously measured in the simulated combustion gas atmosphere at $450^{\circ} \mathrm{C}$ by using thermogravimetry. Figure 7 shows the continuous weight gain curves of mild steel in gas $\mathrm{A}$ and gas $\mathrm{H}$ at $450^{\circ} \mathrm{C}$. In gas $\mathrm{H}$ the corrosion progressed approximately following parabolic rate law. On the other hand, the corrosion rate law in gas A was more complex than in gas $\mathrm{H}$. The corrosion rate followed a linear rate law at the first stage of corrosion, but the gradient tend to decline with time. It is highly probable that more than one factor is determining the corrosion rate in this atmosphere at each stage. Namely, the reaction between metal and gas species determined the corrosion rate at the beginning of corrosion, but later, when the metal surface was covered with the protective scales, the outward cationic diffusion determined the corrosion rate. 


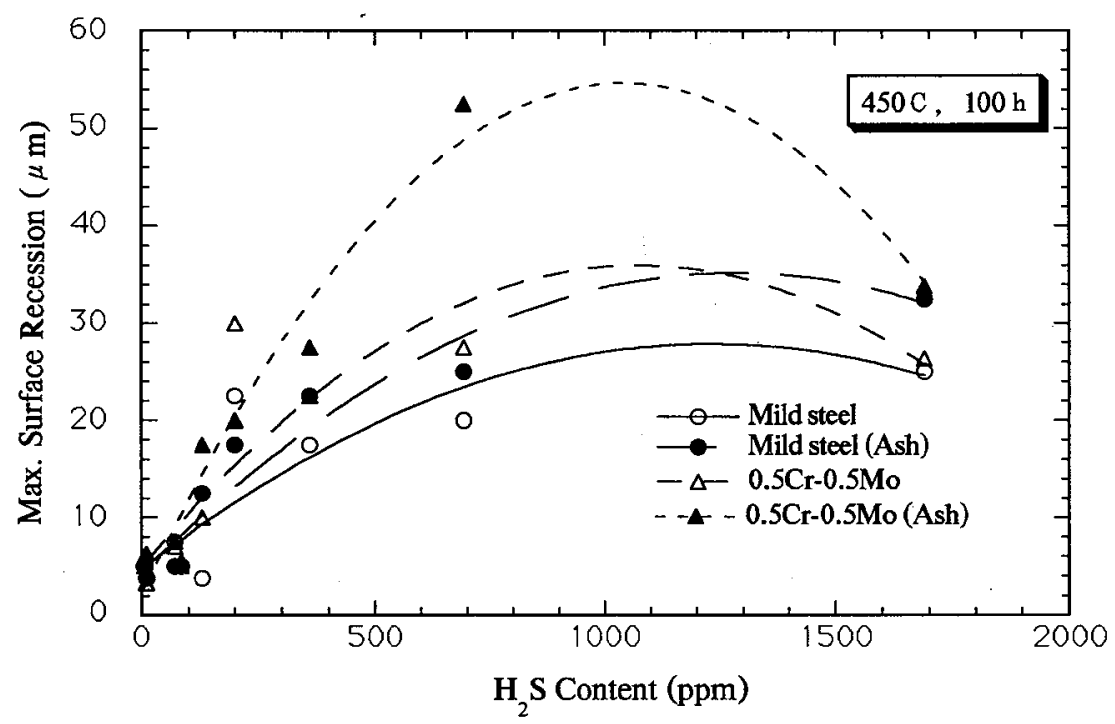

Fig. 6. - Effect of $\mathrm{H}_{2} \mathrm{~S}$ content on the corrosion rates of steels.

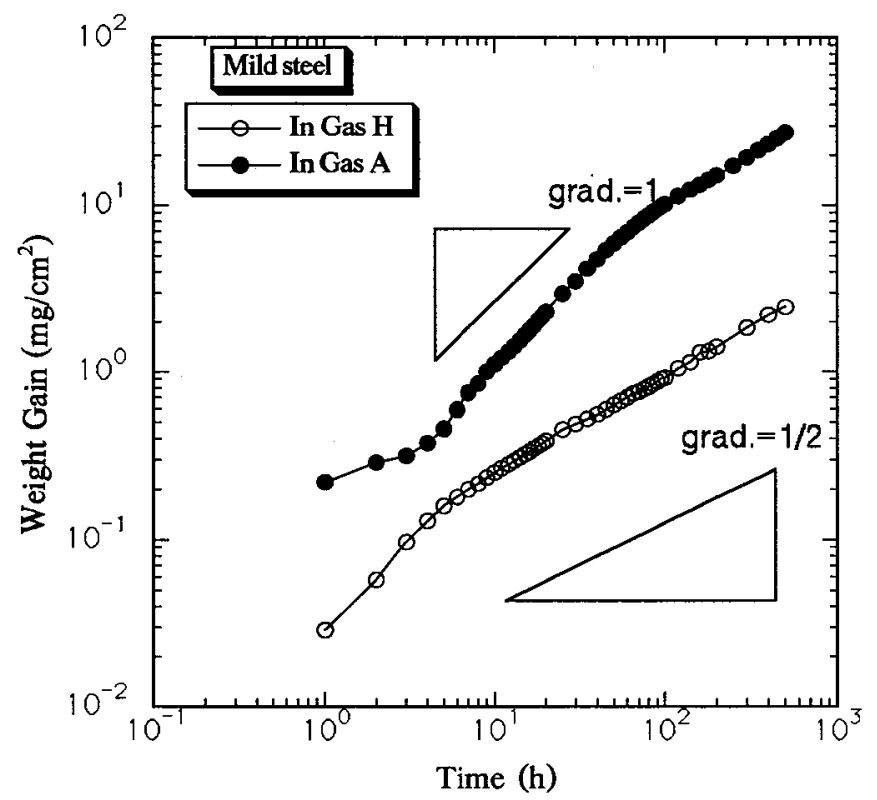

Fig. 7. - Continuous weight gains of mild steel in gases $\mathrm{A}$ and $\mathrm{H}$ at $450^{\circ} \mathrm{C}$.

\section{Conclusion.}

The corrosion resistance of a mild steel and $0.5 \mathrm{Cr}-0.5 \mathrm{Mo}$ steel has been evaluated in simulated combustion gases at $450^{\circ} \mathrm{C}$. The results are summarized as follows:

1) The corrosion behavior can be predicted by the Fe-S-O phase diagram at tube surface temperature and pseudo-equilibrium $P_{\mathrm{S}_{2}}$ and $P_{\mathrm{O}_{2}}$ based on $\mathrm{H}_{2} \mathrm{O}: \mathrm{H}_{2}$ at $1200^{\circ} \mathrm{C}$ for simu- 
lated combustion gases.

2) Ash deposit increases the corrosion rates slightly. It is considered that ash deposit acts as catalyst and alters the gas composition to the low temperature equilibrium state.

3) The corrosion rates increase with $\mathrm{H}_{2} \mathrm{~S}$ content in a certain range, but tend to saturate in a high $\mathrm{H}_{2} \mathrm{~S}$ level region.

4) The corrosion rate of mild steel follows the parabolic rate law in an oxidizing atmosphere. In a reducing atmosphere it follows a periodically linear or a parabolic rate law.

\section{References}

[1] Trade- Offs in $\mathrm{NO}_{x}$ Control, EPRI Journal (January/ February 1982) p.18.

[2] PERkins R.A., BAKKeR W.J., Materials for syn gas coolers, EPRI AP-2518 Project 16545 Final Report (August 1982).

[3] Harb J.N., Smith E.E., Fire-side de Corrosion in PC-Fired Boilers, Prog. Energy Combust. Sci., Vol. 16 (1990) p.169.

[4] Chou S.F., Daniels P.L., Rodgers L.W., Theus G.J., EskinaZI D., Fire-side corrosion in low- $\mathrm{NO}_{x}$ combustion systems, Proc. Symp. Stationary Combustion $\mathrm{NO}_{x}$ Control Volume !: Utility Boiler Applications (1985) p.19-1. 